\title{
CHARACTER BUILDING IMPLEMENTATION MODEL: A REVIEW ON ADAB AKHLAK LEARNING
}

\author{
Muhammad \\ Mataram Islamic State University, NTB, Indonesia \\ muhammad83@uinmataram.ac.id
}

\begin{abstract}
The implementation of the 2013 curriculum for strengthening character building has many obstacles. Teacher's understanding, limited resources, and mass media negative impact are identified as the hindrance of the implementation. The article aims to explore character building based on Adab Akhlak learning. For this purpose, the research uses the qualitative approach based on a literature review. The research data was obtained from research result which has been published (secondary research). The data findings were compiled, decoded, categorized, illustrated in a matrix, and then drawn conclusion and verification. The research result shows that it did not achieve character-building maximally because, first, it was lack of adequate follow-up after assessment/evaluation result; second, the cognitive aspect was always dominant in determining student's achievement and learning completion. The values of attitude and behavior were not regarded as an authoritative reference to determine a student's learning completion. The orientation of attitude and behavior assessment become student's report "ornament", however, it had not been accompanied by adequate followed-up, for instance, in the form of reward which can encourage on the developing and maintaining character values owned, and punishment which provide a deterrent effect and eliminate the possibility to repeat the violation. The success of character building in MA Plus Abu Hurairah Mataram lies on the courage to determine punishment policy for the offenders and consistent with the rules. The attitude and behavior become the standard measurement in assessing learning completion, it had $50 \%$ percentage in determining graduation.
\end{abstract}

Keywords: character building, habituation, exemplary, reward, punishment, moral learning, akhlak.

\section{INTRODUCTION}

It cannot be denied that globalization has an effect on many aspects of life in the world, positive or negative. Morality degradation of the nation is one of the negative impacts of globalization (Kurniawan, 2015a). 
However, the source of many problems struck this nation, such as it is suspected due to educational foundation, policy, and implementation which have not met the expectation yet. Because education is the beginning of all aspects in life (Ana, 2016).

Every nation highly expects on their education. Moreover, it has been agreed together that education is the nation's pillar (Jalil, 2016). Through education, the future of a nation is constructed with a strong foundation (Sulhan, 2010). And only with a good education, a nation can turn to a better future (Ariyanti, 2017).

The essence of education is to form a human's character (Muhammad, 2013). Education is interpreted as a process in changing a person or a group of people's attitudes and behavior in the effort of maturing humans through learning and training (Kemendikbud, 2016). Regarding to this, Constitution Number 20 in 2003 on National Education System defines that education, especially National Education, functions in developing nation's civilization as well as building the character to enrich the life of a nation, aims at developing student's potential to be a human who believes and fear to God the Almighty, noble in character, healthy, skillful, smart, creative, independent, and becomes a democratic citizen as well as accountable. Or in the other words, education is an effort to build a character.

The Indonesian nation needs to have nationality insight instilled through character building (Ngamanken, 2014, p. 87). It is a system in instilling character values covering the component of knowledge, awareness or willingness, and action in implementing the values, both toward God the Almighty, ourselves, other people, environment, or nation, so that, human have a good character (Mardiyah, 2017; Omeri, 2015).

According to the character-building team of the Ministry of National Education (2010, pp. 19-21), character building is through various steps, 
i.e. knowing step, acting step, and habit step. Character is not limited merely to knowledge. A person who has knowledge of goodness, it is uncertain that a person can act in accordance to the knowledge owned, if that person is not trained (become habit) to implement the virtue.

Nation's character building can be carried out by following a person's character development. Nevertheless, because humans live in a certain social and cultural environment, the individual character building of a person can only be done in the related social and cultural environment as well (Omeri, 2015, p. 468). Hence, until today, character-building conducted in the school, society, and formal education need to be improved to reach internalization of the values for fostering morals towards the happiness of individual, family, and Indonesian society (Ngamanken, 2014, p. 87).

The awareness on the importance to strengthen the character building toward the children of the nation, as the answer to the challenges of moral decadence (Ana, 2016; Jalil, 2016; Kurniawan, 2015b; Mardiyah, 2017; Omeri, 2015; Pawitasari et al., 2015; Unwanullah, 2019; Wulandari, 2016). The 2013 curriculum or so-called K-13 emphasizes the certain competencies achievements on the domains of spiritual and social attitude, which each of it symbolizes with KI-1 and KI-2; knowledge (KI3), and skill (KI-4)”. In measuring competence achievement, the assessment proposed, for instance, were carried out with authentic assessment. This kind of assessment is expected to become an objective assessment, so that, there are improvements and balance among competence attitude, skill, and knowledge (Hidayat, 2013, p. 119). However, in reality, this competence achievement may not always be the same as the expectation. There are still many obstacles in applying character building (Jatmiko, 2018), so, the good and universal character is not strongly instilled. 
Some of the findings show that the hindrance lies on the unsupportive student's environment, other finding shows that learning process does not work maximally, another cause is the limited resources, and mass media negative impact (Dulumina, 2009). Triatmanto (2010) pointed that the challenges in implementing character-building are on the environment and information technology, educational personnel, and policy as well as curriculum. According to the writer, character-building did not reach the maximal achievement, apart had mentioned above, it is situated in the weakness of the follow-up from the assessment/evaluation results. Assessment integration of K-13 does not fully enforce; cognitive aspect still dominates especially its percentage in determining achievement and grade promotion. The values of attitude and behavior which become the main point in K-13 were not authoritative to determine student's graduation. Orientation of attitude and behavior assessment only becomes 'ornament' in student's rapport, with grading praise as good or less and so forth, as well as recommendation to be maintained, upgraded or fostered. However, it did not accompany with sufficient follow-up, not just reward which makes enthusiasm in developing and maintaining character values owned, but punishment as well to give deterrent effect and eliminate the opportunity to repeat the violation.

This article tries to explore morals education or character building in Islamic Senior High School (Madrasah Aliyah) Plus Abu Hurairah Mataram through Adab Akhlak learning - in this article, character, morals, and akhlak are defined as the same, not different, and still substantially the same. MA Plus Abu Hurairah has an excellent reputation and has Wahabi-Salafi features theologically. In terms of the school's policy, the student's attitude and behavior values are converted become $50 \%$ to determine the achievement and student's graduation. According 
to the researcher, the policy gives a significant impact on the character building.

\section{METHOD}

The method of this study is a qualitative research based on literature review. The focus of this study is directed to the moral learning implementation or courtesy learning toward student's character building or student's morals. The research data were obtained from the previous researches which had been published in el-hikmah 7, no. 2 (2013). Therefore, the study is categorized as secondary research or desk research (Glass, 2016). Afterward, the researcher undertook a search of library sources in books, scientific article journals which can be accessed freely on some websites, by utilizing search engines such as Google Scholar, Garuda LIPI, and DOAJ. The data findings were compiled, decoded, illustrated into the matrix, and then drawn conclusion and verification (Lotto, 1986; Miles et al., 2014).

\section{FINDINGS AND DISCUSSION}

\section{Adab Akhlak Learning in MA Plus Abu Hurairah Mataram}

Study in behavioristic point of view is the result of interaction between respond and stimulus (Slavin, 2000, p. 143). A person is regarded had studied something if that person shows changes in behavior. The term of learning is more inclined to the effort to make the student as an active party (student-centered education) in the role of a learner (Yusuf, 2007, p. 3). In the other words, learning is the teacher's effort to uphold learning experiences in order to achieve behavioral changes.

Adab Akhlak learning in MA Plus Abu Hurairah Mataram is arranged into two main parts, those are (1) as a subject, and (2) as core integrator of all subject as well as attitude and behavior standard. 
First, Adab Akhlak learning as a subject. Adab Akhlak learning is one of the 20 subjects collected within the distribution of subjects in Ma'had Abu Hurairah Mataram. This subject must be undertaken by all educational levels under Abu Hurairah Mataram Islamic Boarding School. Besides Adab Akhlak, other subjects were also taught, such as al-Qur'an, Hadith, Ilmu Tafsir, Ilmu Hadith, Fiqh, Ushul Fiqh, Aqidah, Ilmu Tajwid, Tahfizul Qur'an, SKI, Arabic Language, Muhaddatsah, Nahwu, Shorof, Khot, Hafalan Hadith, Imla', Manhaj, Takhrij Hadith, and Faro'id. Adab Akhlak subject has 1 Credit per semester or 1 -hour lesson within 1 week. The learning material design follows the order of the chapters and sub-chapters in the discussion within Kitabul Adab by Fuad bin Abdul Aziz asy-Syalhub (2002). The main theme consisted of 22 chapters, they are courtesy for Tilawah al-Qur'an, courtesy to greet, courtesy when requesting for permission, courtesy in visiting, courtesy in respecting guest, courtesy in a congregation, courtesy in speaking, courtesy in drinking and eating, courtesy in the restroom, courtesy when present in the mosque, courtesy in sleeping, courtesy in journey, courtesy visiting the sick, courtesy in dressing and make-up, courtesy in riding, courtesy in walking, courtesy as neighbour or visiting, courtesy when hungry, courtesy in entertain the muslim jama'ah, courtesy in ushratunnisa', and courtesy in praying. Each of the chapters is discussed until finish, in order, and consecutively. The learning material is delivered using bandongan (collective learning) and sorogan (independent learning) method. Chaplain delivers the lesson by reading the book, interpreting, and explaining, while the students listen, and pay attention to the text in the book by giving mark and punctuation in the chapter read. Once in a while, it is used for independent learning, where students are appointed to read, translate, and interpret the meaning (Muhammad, 2013).

Second, besides as a subject, Adab Akhlak also a core integrator of all subjects as well as standard in attitude and behavior. As a core integrator 
of all subjects and learning, the Adab Akhlak learning concept must be as a standard of attitude and behavior in every student's learning activities, inside and outside the class, worship, and muamalah, related to God or related to the creation. It is weighted 1 Credit in Adab Akhlak learning as the basis of concept understanding. Later on, it is a value transfer process, character values internalization through all student's interaction with all subjects. As a reward for it, Morals become the standard score or reference of all subjects to determine student's graduation as much as 50\% (Muhammad, 2013).

Therefore, Morals teaching, as explained above carried out in stages, i.e. learning material acceptance or transfer knowledge. This takes the first form of learning mentioned above, as a scheduled subject for 1-hour lesson every week. Afterward, the enrichment stage and transfer of value through unlimited time and space in every side of a student's life. Both forms of Adab Akhlak learning are one complete union. During the transfer, the knowledge process takes place in the class, at the same time it is carried out the transfer of value, enrichment, and realization of those morals' values.

Generally in Indonesian, the implementation of moral learning or character is held through integrated learning, religion subject and other relevant subjects, not as an independent subject of its own (Daulay, 2004, p. 220). It is the same with the character-building 2013 curriculum. Every Islamic private educational institution provides character-building correspond to its organization affiliation, for instance, Muhammadiyah institution through Al-Islam dan Muhammadiyah Subject (Saswandi \& Sari, 2019; Widodo, 2019), Nahdhlatul Ulama educational institution through Aswaja, and Ke-NU-an subject (Anggraeni, 2020; Rohman, 2019; Shodiq, 2015), and Nahdlatul Wathan educational institution through KeNW-an subject (Azmi \& Wardi, 2020; Saparudin, 2017). 
As mentioned above, every educational institution presents a subject to strengthen in conventional character as well as strengthen its organizational character. It is the same with MA Plus Abu Hurairah Mataram, it strengthens character building through Morals subject (Muhammad, 2013). The reference book selected is 'Kitab Adabul Akhlak'. Because Morals subject is based on learning the reference book, it is required science tool programmed within the subject of al-Qur'an, Hadith, Science of Interpretation, Science of Hadith, Fiqh, Ushul Fiqih, Aqidah, Science of Tajweed, Tahfizul Qur'an, SKI, Arabic, Muhaddatsah, Nahwu, Shorof, Khot, Memorizing Hadith, Imla', Manhaj, Takhrij Hadith, and Faro'id.

\section{Developing student's cognitive, affective, and psychomotor potential}

The essence of studying is the changes within a person, the changes mainly will create a new skill, and the changes occur because of the intended effort (Hamzah, 2012). The achievement of the learning purposes cannot be separated by the education objective. Athiyah $\mathrm{Al}$ Abrosyi (1987, pp. 1-4) stated that Islamic education's purpose is to form humans with human character, harmonious and balance, not only in science and religion, but also skill. In Constitution Number 20 in 2003 on National Education System stated that national education aims to develop student's potential to become human who believes and fear on God the Almighty, noble in character, healthy, intelligent, skillful, creative, independent, and becomes democratic citizen as well as accountable. If it is looked thoroughly at the two formulations of educational goals above, it is obvious that education covers three domains as divided by Bloom et al. (1956), which are, cognitive, affective, and psychomotor domains.

The cognitive domain consists of 6 levels, refer to Bloom's taxonomy as the revision result of Anderson et al, those are: remembering, understanding, applying, analyzing, evaluating, and creating. The affective 
domain consists of 5 levels, i.e.: receiving phenomena, responding to phenomena, valuing, organization, internalizing values (characterization). And psychomotor domain covers 6 levels, i.e.: perception (awareness), set, guided response, a mechanism (basic proficiency), complex overt response (expert), adaptation, origination (Anderson et al., 2001).

Adab Akhlak learning orientation based on book learning in the class is a cognitive process to give a comprehensive understanding of morals which is intended as a foundation of moral/value. Hence, material content is delivered through the collective learning (Bandongan) and independent learning (Sorongan) approach. Collective learning is centered on the teacher, and in its application, it gets a greater portion of the class learning process compared to the independent learning method. Teachers become centered on knowledge, it is active to deliver understanding the concept through preach, read, and interpret, while the student is passive.

Knowledge and comprehension are given not merely in Morals subject. In completing a student's cognitive development, other relevant subjects contribute greatly to enrich comprehension in the school environment, boarding, and wider environment in a student's life. Using habituation and exemplary method given, it has a greater influence on the students' moral attitude, character building, and development.

Habituation creates a routine, which seems to be forced, but gradually it will be instilled within the students' personality. Building positive awareness, it needs to be supported by the correct understanding (knowledge on the courtesy). In their behavior, students need an example on a good figure in attitude and conduct, therefore, it requires a teacher's exemplary, mushrif, headmaster, and all the existing elements.

Outside of school hours, responsibility is fully charged to a boarding school administrator, as overseer, foreman, supervisor, assistant or coassistant, and counselor that is called by mushrif. The Mushrif has the 
right to assess and respond in fostering and reporting the students' moral development, also when there is a violation.

The parameter is how far of the students' acceptance, respond to a lesson given, accuracy in doing an assignment, and violation committed by the students. The level of violation becomes parameter of success or not in education given. On the next step, to instill student's positive attitude in responding to the lesson, regulation, and set of courtesies taught, so evaluation for passing the subject and grade promotion is $50 \%$ determined by how far the attention to the score, the noble character is showed by the student on lesson's acceptance or common situation in daily life.

Example of sub-chapters in Salam Chapter are as follows: (a) It is sunnah to greet when meet and obliged to answer; (b). Nature in greeting; (c). It is Makruh to start greeting with the sentence of 'alaikum salam; (d). Sunnah in repeating 3 times greetings if in the congregation or doubts if the greeting is not heard; (e). Sunnah in raising voice greeting and answering it; (f). Greeting Sunnah both for an unknown person or not; (g). Sunnah to start and prioritize greetings; (h). Greeting is sunnah for people in riding to walking people, people who are walking to sitting, the few to the greater crowd, the small to the bigger; (i). greetings to the not mahram women; (j). Greeting is sunnah for children; (k). Greeting of the wake to the sleep; (1). prohibition to start greeting toward other religious believers; (m). replying other believer's greeting; (n). allowed to greet in a congregation of Muslim and mushrik; (o). allowed to greet with the sign because of udzur; (p). allowed to greet the praying person and reply with a sign; (q). allowed to greet a person who recites Qur'an and must be replying it; (r). Makruh to greet people in a restroom; (s). It is sunnah to greet when entering a house; $(\mathrm{t})$. replying greeting to people who address and greet back; (u). prioritizing to respect Mosque upon people inside the Mosque; (v). Makruh to greet during Friday Preach; (w). 
Greet immoral people and start to greet; (x). Sunnah to greet when meeting in a congregation and before leaving. (al-Syalhub, 2002, pp. 381395)

Subs-theme in the greeting chapter above is discussed in order and completed. And on practical level, the reality of student's greeting is the same with the content in the reference book (Muhammad, 2013). Actually, what is explained above shows attitude, practice, and interpretation of student toward norms taught. This becomes a proposition showing significance in Adab Akhlak learning informing behavior and moral pattern of the students. As Clark conveyed in Abdul Wahid dan Atun Wardatun (2009, p. 5) that education and teaching involvement has a clear foundation with the hypothesis that a person can be religious or actualizing the religious potential only with the interference of other parties (aspect/factor).

Effective learning is created by a conducive situation that allows a well-interaction process to take place. Thus, quoting from Abdul Rachman Shaleh's (2006, p. 223) opinion, in such a situation, it needs to try for the student to be always interested and pay attention, the student actively participated in the learning experience; the teacher gives integrated experience in the learning process, and the occurrence of positive encouragement within the student to study. Adab Akhlak learning in MA Plus Abu Hurairah Mataram does not only touch cognitive and effective student's development, but also the psychomotor. The indicator is that the students' learning interaction do not only listen, but also pay attention (by seeing), practice, and implement those experiences in their life.

In the learning process, the student must be empowered to be able and want to conduct in enriching their learning experiences (learning to do) by increasing interaction with their neighborhood both physical, social, or environmental, so that, it can build knowledge (learning to 
know) and their self-confidence (learning to be). The opportunity to interact with many diverse individuals or groups (learning to live together) will shape their personality to understand diversity and generate a positive and tolerant attitude toward diversity and life differences (Shaleh, 2006, p. 225).

Refer to the above opinion, it can be said that Adab Akhlak learning process in MA Plus Abu Hurairah can be said as effective, the reasons are: learning to do is showed that a student is encouraged to be able and want to conduct good deed, not just in theoretical level, but also in the application. Learning to know is indicated with knowledge and observation in building knowledge and self-confidence (learning to be). Such learning interaction will develop student's personalities (learning to live together).

Based on the above analysis, Adab Akhlak learning in MA Plus Abu Hurairah has an important role in changing the student's behavior. The behavior changes are seen from the students who always take the line to perform obliged congregational prayer in the Mosque, have tradition to greet, wear trousers according to sunnah /not isbal, routinely follow after maghrib recitation. The practices indicate the real changes in the student's personality. Changes are not only in intellectual-religion (cognitive) domain, but also in affective and psychomotor domains. These findings strengthen Wahid \& Wardatun (2009, p. 5) thesis that supports education and teaching factor in shaping religious attitude. Character building is implemented through concept knowledge (knowing), implementation (acting), and habituation (habit), as formulated by Character Building of Kemendiknas (2010) team.

The essence of character building is in forming attitude and personality. Therefore, its main orientation is value internalization. Thus, it is demanded to carry out education with sustainable, and cultural education (Shaleh, 2006, p. 223). Character building in the school will not 
succeed well if the environment supports such as society's life and its technology do not help much. The television show and other media, which currently become a daily routine for the student, need to regulate their time and content to be harmonious with the character building. Hence, it is required a figure in regulation and broadcasting supervision who truly understands the education (Triatmanto, 2010). It is as Adab Akhlak learning in MA Plus Abu Hurairah. Adab Akhlak learning even though it stands for its own, but moral building, supervision, and counseling are conducted in integrative, continuous, and by creating an educational climate which is orientated on the formation and fosters on the morals.

Sustainable education is shown with a continuous relation between education inside and outside (boarding) the class. Integrative education is indicated with the occurrence of morals values that is existed in many subjects by the teacher while teaching. Forming an educational climate which is orientated in shaping and fostering akhlak al-karimah is shown with the involvement of all existing elements under the school and the boarding as the supervisor, and counselor surely being supported with the school rules. It desires the creation of a school climate that has an orientation on fostering akhlak al-karimah.

Whether it was found any violation, automatically the counseling is conducted based on the violation. If the mushrif or chaplain finds a student violating norms, ethics, or rules, the student (read: offender) is summoned and advised.

Violation becomes serious attention for all boarding residents. The form of seriousness is seen by the swift response to the violation. Moreover, every violation becomes evaluation and counseling learning material given to all of the students. Evaluation result routinely reported to students' parents every weekend (Muhammad, 2013). Because the violation is understood as an indication of the wrong learning process, 
the increasing violation quantity means that there is something wrong in the learning process, and this is sourced in the Morals.

\section{CONCLUSION}

The procedure of character building as has been understood must pass three steps, which are knowing, acting, and habit. Until now, character-building strengthening is taught only through the religious subject, civic education, and relevant subject. Therefore, curriculum counselor in the educational unit can freely seek for the formulation of character knowledge correspond to the affiliation interest.

Character building model based on the book learning applied in MA Plus Abu Hurairah Mataram, which arranged in Morals subject is contributed as the value basis in character knowledge stage. The basis of this value will be a reference of the entire learning activities to direct student's social-spiritual potential attitude and behavior development, both inside and outside the class.

There are many obstacles to implement the character building. Its implementation success depends on the support of the learning environment. High discipline toward applicable rules, and upholding punishment toward violation is very much contributing to organize and achieve the character building.

\section{BIBLIOGRAPHY}

al-Albrasyi, M. A. (1987). Dasar-dasar Pokok Pendidikan Islam (B. A. Gani \& D. Bahry L.I.S., Trans.). Bulan Bintang. al-Syalhub, F. bin A. A. (2002). Kitab al-Adab. Dar al-Qasem li an-Nasyri wa atTauzi.

Ana, S. (2016). PENDIDIKAN KARAKTER SEBAGAI PILAR PEMBENTUKAN KEPRIBADIAN BANGSA. PENDIDIKAN KARAKTER SEBAGAI PILAR PEMBENTUKAN KEPRIBADIAN BANGSA, XXVIII(98), 1-6. 
Anderson, L. W., Krathwohl, D. R., Airasian, P. W., Cruikshank, K. A., Mayer, R. E., Pintrich, P. R., Raths, J., \& Wittrock, M. C. (2001). A Taxonomy for Learning, Teaching, and Assessing: A Revision of Bloom's Taxonomy of Educational Objectives (Abridged Edition). Addison Wesley Longman, Inc.

Anggraeni, K. (2020). PEMBELAJARAN MATERI ASWAJA/ KE NU-AN DALAM MENUMBUHKAN PERILAKU SOSIAL PADA SISWA DI MTS TERPADU HUDATUL MUNA JENES PONOROGO [Diploma, IAIN Ponorogo]. http://etheses.iainponorogo.ac.id/11427/

Ariyanti, L. (2017). Membangun Pendidikan Karakter di Sekolah Dasar Melalui 6 Kebajikan Positif Universal. ELSE (Elementary School Education Journal): Jurnal Pendidikan dan Pembelajaran Sekolah Dasar, 1(2b), Article 2b. http://dx.doi.org/10.30651/else.v1i2b.1058

Azmi, S., \& Wardi, F. (2020). Muhammad Zainuddin Abdul Madjid: The Pioneer of Islamic Education in Lombok Community West Nusa Tenggara, Indonesia. Khalifa: Journal of Islamic Education, 4(1), 19-31. Bloom, B. S. (Ed.). (1956). Taxonomy of Educational Objectives: The Classification of Educational Goals (Handbook 1, Cognitive Domain). David McKay Company.

Daulay, H. P. (2004). Pendidikan Islam dalam Pendidikan Nasional. Kencana.

Dulumina, G. B. (2009). PEMBINAAN AKHLAK PADA MADRASAH ALIYAH PONDOK PESANTREN ALKHAERAAT PUSAT PALU. HUNAFA: Jurnal Studia Islamika, 6(2), 153-178. https://doi.org/10.24239/ jsi.v6i2.129.153-178

Glass, G. V. (2016). Primary, Secondary, and Meta-Analysis of Research1: Educational Researcher. https://doi.org/10.3102/0013189X $\underline{005010003}$

Hamzah, S. H. (2012). Aspek Pengembangan Peserta Didik: Kognitif, Afektif, Psikomotorik. Dinamika Ilmu: Jurnal Pendidikan, 12(1), Article 1. https://doi.org/10.21093/di.v12i1.56 
Hidayat, S. (2013). Pengembangan Kurikulum Baru. Remaja Rosdakarya.

Jalil, A. (2016). Karakter Pendidikan untuk Membentuk Pendidikan Karakter. Nadwa, 6(2), 175-194. https://doi.org/10.21580/nw.2012.6.2.586

Jatmiko, A. (2018). Pengembangan Instrumen Penilaian Autentik Kurikulum 2013 Aspek Afektif Dalam Mata Pelajaran PAI Kelas VII Di Smpn 3 Kalasan. EDULAB: Majalah Ilmiah Laboratorium Pendidikan, 3(2), 7392.

Kemendikbud. (2016). KBBI Daring. https://kbbi.kemdikbud.go.id/ entri/pendidikan

Kurniawan, M. I. (2015a). Tri Pusat Pendidikan Sebagai Sarana Pendidikan Karakter Anak Sekolah Dasar. PEDAGOGIA: Jurnal Pendidikan, 4(1), 41-49. https://doi.org/10.21070/pedagogia.v4i1.71

Kurniawan, M. I. (2015b). Tri Pusat Pendidikan Sebagai Sarana Pendidikan Karakter Anak Sekolah Dasar. PEDAGOGIA: Jurnal Pendidikan, 4(1), 41-49. https://doi.org/10.21070/pedagogia.v4i1.71

Lotto, L. S. (1986). Qualitative Data Analysis: A Sourcebook of New Methods: Matthew B. Miles and A. Michael Huberman. Educational Evaluation and Policy Analysis, 8(3), 329-331. https://doi.org/10.3102/ $\underline{01623737008003329}$

Mardiyah, M. (2017). NILAI-NILAI PENDIDIKAN KARAKTER PADA PENGEMBANGAN MATERI AJAR BAHASA INDONESIA DI KELAS IV SEKOLAH DASAR. TERAMPIL: Jurnal Pendidikan dan Pembelajaran Dasar, 4(2), 31-47. https://doi.org/10.24042/terampil.v4i2.2216

Miles, M. B., Huberman, A. M., \& Saldana, J. (2014). Qualitative Data Analysis: A Sourcebook of New Methods: Matthew B. Miles and A. Michael Huberman (4th ed.). SAGE Publications. https://doi.org/10.3102/ $\underline{01623737008003329}$

Muhammad. (2013). Peranan Pembelajaran Adab Akhlak dalam Membentuk Akhlakul Karimah Siswa di Madrasah Aliyah Plus (MAP) Abu Hurairah 
Mataram. el-Hikmah: Jurnal Kajian dan Penelitian Pendidikan Islam, 2, 49-79.

Ngamanken, S. (2014). Pentingnya Pendidikan Karakter. Humaniora, 5(1), 72-87. https://doi.org/10.21512/humaniora.v5i1.2983

Omeri, N. (2015). PENTINGNYA PENDIDIKAN KARAKTER DALAM DUNIA PENDIDIKAN. MANAJER PENDIDIKAN, 9(3), 464-468.

Pawitasari, E., Mujahidin, E., \& Fattah, N. (2015). Pendidikan Karakter Bangsa dalam Perspektif Islam (Studi Kritis Terhadap Konsep Pendidikan Karakter Kementerian Pendidikan \& Kebudayaan). Ta'dibuna: Jurnal Pendidikan Islam, 4(1), 1-20. https://doi.org/10.32832/ tadibuna.v4i1.573

Rohman, A. A. (2019). PEMBELAJARAN KE-NU-AN DALAM MENANAMKAN NILAI-NILAI ISLAM AHLUSSUNNAH WAL JAMA'AH AN-NAHDLIYAH DI MA MA'ARIF NU 1 SIRAU KEMRANJEN BANYUMAS [Skripsi, IAIN Purwokerto]. http://repository.iainpurwokerto.ac.id

Saparudin, S. (2017). MERAWAT ASWAJA DAN SUSTAINABILITAS ORGANISASI: Analisis Praksis Pendidikan Ke-NW-an. EL-HIKMAH: Jurnal Kajian Dan Penelitian Pendidikan Islam, 11(1), 101-122.

Saswandi, T., \& Sari, A. P. (2019). Analisis penerapan nilai-nilai Al Islam dan Kemuhammadiyahan dalam perkuliahan. Jurnal EDUCATIO: Jurnal Pendidikan Indonesia, 5(1), 27-34. https://doi.org/10.29210/ $\underline{120192327}$

Shaleh, A. R. (2006). Madrasah dan Pendidikan Anak Bangsa; Visi Misi dan Aksi. RajaGrafindo Persada.

Shodiq, S. (2015). Transmisi Ideologi Ahlussunnah Wal Jama'ah: Studi Evaluasi Pembelajaran Ke-Nu-an di SMA Al-Ma'ruf Kudus. Nadwa, 9(2), 183-198.

Slavin, R. E. (2000). Educational Psychology: Theory and Practice (Sixth Edition). Allyn and Bacon.

Sulhan, N. (2010). Pendidikan Berbasis Karakter. Media Utama. 
Tim Pendidikan Karakter Kemendiknas. (2010). Pembinaan Pendidikan Karakter di Sekolah Menengah Pertama.

Triatmanto, T. (2010). TANTANGAN IMPLEMENTASI PENDIDIKAN KARAKTER DI SEKOLAH. Jurnal Cakrawala Pendidikan, 1(3), Article 3. https://doi.org/10.21831/cp.v1i3.245

Unwanullah, A. (2019). IMPLEMENTASI PENDIDIKAN KARAKTER AKHLAK MULIA PADA SEKOLAH MENENGAH PERTAMA BERBASIS ASRAMA DI TUBAN. Jurnal Teladan: Jurnal Ilmu Pendidikan dan Pembelajaran, $4(1), 67-82$.

Wahid, A., \& Wardatun, A. (2009). Tendensi Teks: Ambiguitas Visi Sosial Buku PAI SMU Depag RI dan Hasil Bahtsul Masa'il NU. Alam Tara Institute.

Widodo, H. (2019). PENGUATAN PENDIDIKAN KARAKTER DI SD MUHAMMADIYAH MACANAN SLEMAN YOGYAKARTA. Lentera Pendidikan: Jurnal Ilmu Tarbiyah dan Keguruan, 22(1), 40-51. https://doi.org/10.24252/lp.2019v22n1i4

Wulandari, T. (2016). REKAYASA SOSIAL KOLABORASI PENDIDIKAN KARAKTER DAN PENDIDIKAN MULTIKULTURAL: PRAKSIS DI YAYASAN PERGURUAN SULTAN ISKANDAR MUDA. Jurnal Pembangunan Pendidikan: Fondasi Dan Aplikasi, 4(2), 186-193. https://doi.org/10.21831/jppfa.v4i2.12424

Yusuf, C. F. (Ed.). (2007). Inovasi Pembelajaran Pendidikan Agama Islam (SMP). Penacitasatria. 